\title{
MEMBANGUN SINERGI PEMAHAMAN MEMBACA DENGAN MENGGUNAKAN STRATEGI PQ4R (PREVIEW, QUESTION, READ, REFLECT, RECITE, AND REVIEW) DI KELAS VI SEKOLAH DASAR
}

\author{
Faisal \\ PGSD FIP UNIMED \\ Surel : faisalpendas@gmail.com
}

\begin{abstract}
ABSTRAK
Efektivitas pembelajaran membaca pemahaman di kelas VI Sekolah Dasar (SD) mutlak diperlukan. Hal ini diungkapkan karena masih rendahnya pemahaman siswa dalam membaca. Rendahnya pemahaman membaca terjadi karena kurang terfasilitasinya siswa dengan tahapan dan teknik membaca yang tepat. Mengadopsi kekurangan itu, perlu dilakukan upaya perbaikan proses pembelajaran membaca pemahaman dengan strategi pembelajaran yang sesuai. Salah satu strategi yang dapat mengadopsi tahapan dan teknik membaca pemahaman secara tepat adalah strategi PQ4R. Menguji efektivitas penggunaan strategi PQ4R, telah dilakukan Penelitian Tindakan Kelas (PTK) dengan empat tahap kegiatan utama, yaitu: perencanaan, pelaksanaan, pengamatan, dan refleksi. Hasil penelitian menunjukkan bahwa strategi PQ4R dapat meningkatkan keterampilan siswa dalam membaca pemahaman di kelas VI SD. Dengan demikian, penggunaan strategi PQ4R layak dipertimbangkan sebagai upaya membangun sinergi pemahaman membaca siswa di kelas VI SD.
\end{abstract}

Kata kunci: membaca pemahaman, strategi PQ4R, kelas VI SD

\section{PENDAHULUAN}

Pembelajaran bahasa
Indonesia di SD memuat empat
keterampilan berbahasa, yaitu
mendengarkan, berbicara, membaca,
dan menulis. Keempat keterampilan
itu perlu diberikan titik terang proses
pembelajaran yang jelas dan
terstruktur dengan baik agar dapat
tercapai secara maksimal. Di antara
keempat keterampilan yang
diungkapkan, yang menjadi salah
satu sorotan utama adalah
keterampilan membaca. Hal ini
sesuai dengan pernyataan bahwa
membaca merupakan salah satu
keterampilan berbahasa yang sangat
penting di samping tiga keterampilan
berbahasa lainnya (Somadayo,

2011:1). Membaca merupakan sarana untuk mempelajari suatu hal sehingga dapat memperluas pengetahuan dan menggali pesanpesan tertulis dalam bahan bacaan. Walaupun demikian, membaca bukanlah suatu pekerjaan yang mudah untuk dilakukan dan perlu bimbingan melalui proses pembelajaran yang tepat. Proses pembelajaran membaca hendaknya melihat secara utuh dan menyeluruh jenis membaca yang dilakukan dan strategi yang tepat untuk digunakan. Hal ini dilakukan karena isi setiap materi pelajaran dapat digali dan dimengerti dengan baik melalui kegiatan membaca yang baik dan benar. 
Pembelajaran membaca di SD dibagi menjadi dua bagian yakni, (1) membaca permulaan di kelas I dan II, (2) membaca lanjut (membaca pemahaman) di kelas III sampai kelas VI SD. Membaca permulaan menekankan pada pengenalan huruf vokal, konsonan, dan diftong sehingga dilakukan dengan membaca nyaring dan lancar (teknik bersuara). Sedangkan membaca lanjut dikatakan juga dengan membaca pemahaman karena berguna untuk melihat kemampuan siswa memahami isi bacaan secara utuh dan menyeluruh. Proses membaca bukan merupakan satu-satunya tujuan dari pembelajaran membaca akan tetapi lebih menekankan pada perolehan hasil dan pemahaman setelah membaca.

$$
\text { Selain apa yang }
$$

diuangkapkan di atas, membaca pemahaman yang baik juga harus dilakukan dengan teknik yang benar. Teknik membaca yang benar antara lain: membaca dengan tidak bersuara, bibir tidak bergerak atau komat-kamit, tidak menggerakkan kepala mengikuti baris bacaan, tidak menunjuk baris bacaan dengan jari, pensil, atau alat lainnya, dan tidak membaca kata demi kata, atau kalimat demi kalimat (Saddhono dan St.Y.Slamet, 2012:66). Kegiatan ini berguna untuk menyerap informasi yang disampaikan penulis dalam setiap bacaan dengan tepat. Selain itu, diperlukan sejumlah aspek yang dapat mendukung keterampilan membaca siswa, antara lain: (1) memiliki kosa kata yang banyak, (2) memiliki kemampuan menafsirkan makna kata, frasa, kalimat, dan wacana, (3) memiliki kemampuan menangkap ide pokok dan ide penunjang, dan (4) memiliki kemampuan menangkap urutan peristiwa yang terjadi dalam bacaan. Meningkatkan keterampilan membaca yang diungkapkan di atas tidak terlepas dari peran guru sebagai ujung tombak proses pembelajaran pada setiap satuan pendidikan yang sesuai dengan Standar Nasional Pendidikan. Sesuai dengan amanat Peraturan Pemerintah Nomor 19 tahun 2005 tentang Standar Nasional Pendidikan bahwa salah satu standar yang harus dikembangkan oleh seorang guru adalah standar proses. Standar proses ini meliputi perencanaan pembelajaran, pelaksanaan proses pembelajaran, penilaian hasil pembelajaran, dan pengawasan proses pembelajaran. Berdasarkan hal tersebut, kemampuan guru menciptakan dan mengondisikan proses pembelajaran sangat menentukan berhasil tidaknya suatu proses pembelajaran dilaksanakan. Begitu juga halnya dengan pembelajaran membaca, menciptakan proses pembelajaran yang efektif dapat dilakukan dengan menggunakan strategi pembelajaran yang tepat.

Penggunaan strategi yang tepat akan menumbuhkan usaha kreatif penemuan sendiri isi bacaan oleh siswa. Proses penemuan itu, selain mengenal jenis teks yang akan dibaca juga dapat dilakukan dengan melakukan prediksi, menemukan 
intisari bacaan, dan meringkas isi bacaan secara tepat. Hal inilah yang dikatakan dengan tahapan membaca. Terdapat enam kegiatan yang dapat dilakukan dalam mencapai kesuksesan memahami isi bacaan, antara lain: (1) mengenali jenis teks, (2) mengenali beberapa macam struktur teks, (3) memprediksi dan meringkas isi dari sebuah teks atau bacaan, (4) membuat rujukan kepada informasi-informasi yang terkandung secara tersirat dalam teks, (5) menentukan makna dari kata-kata yang tidak dikenal berdasarkan konteks dari bacaan, dan (6) menganalisa morfologi dari kata-kata yang belum mereka kenal artinya (Ghazali, 2010:209). Dalam penjelasan yang lain juga dijelaskan bahwa:

Teacher can help students become more activity consumers of information by providing instruction before, during, and after the reading activity. Before reading, teacher can prepare the students for the reading activity by doing some of the following: previewing the reading selection, going over the new vocabulary or difficult words, teaching any needed strategies that students will need to read the material. Teacher can give students a number of questions to think about as they read or they can encourage their students to ask questions about the text material. Teacher can challenge their students to act an investigative reporters while they reading. After reading, students can answer their own questions or the teacher's questions, state the main idea of the selection, summarize it, discuss their feelings toward the material, or discuss how they would rewrite or change the material (Rubin, 1995:137).

Kegiatan-kegiatan yang dipaparkan di atas, dapat dirinci lebih lanjut menjadi tiga kegiatan utama, yaitu (1) pre-reading (prabaca), (2) during-reading (saat baca), dan (3) post-reading (pascabaca) (Stone, 2013:116; Rahim, 2011:99). Tahapan membaca yang diungkapkan akan memberikan pengalaman belajar yang berarti bagi siswa dalam membaca. Pengalaman itu akan terlihat ketika siswa mampu memahami isi bacaan dan menyerap informasi dari bahan yang dibacanya secara utuh dan menyeluruh. Seperti yang telah diungkapkan di atas, peran serta strategi pembelajaran yang tepat merupakan hal pokok yang tidak bisa terlepas dari proses pembelajaran yang dilaksanakan. Oleh sebab itu, strategi pembelajaran yang digunakan merupakan faktor penentu berhasil tidaknya proses pembelajaran membaca diberikan di SD.

Berdasarkan observasi yang dilakukan di kelas VI SD Negeri 10 Lembah Melintang Kabupaten Pasaman Barat Provinsi Sumatera Barat, pembelajaran membaca belum berjalan secara efektif. Hal ini terlihat dari beberapa gejala yang 
muncul, di antaranya: (1) dalam pembelajaran membaca guru belum menggunakan tahap prabaca, saat baca, dan pascabaca secara tepat, sehingga pembelajaran tidak terlaksana sesuai konsep pembelajaran membaca efektif, (2) guru belum mengaktifkan pengetahuan awal siswa, sehingga siswa belum dapat menghubungkan ilmu yang telah miliki dengan materi yang akan dipelajari, (3) belum adanya kegiatan tanya jawab tentang isi bacaan, sehingga siswa kurang memahami apa yang telah dibacanya, dan (4) belum adanya kegiatan refleksi dalam pembelajaran membaca sehingga guru kurang mengetahui kesulitan siswa saat dan setelah belajar membaca, artinya belum terjadi kegiatan interaktif yang baik dalam belajar.

Mengatasi permasalahan yang diungkapkan, perlu dilakukan perbaikan proses pembelajaran membaca secara efektif dengan menggunakan strategi yang tepat. Salah satu strategi yang dapat digunakan untuk mengatasi sesuai dengan permasalahan tersebut adalah strategi PQ4R (Preview, Question, Read, Reflect, Recite, and Review). Hal ini sesuai dengan pendapat Thomas dan Robinson sebagai pencetus strategi PQ4R menyatakan bahwa salah satu strategi yang paling banyak dikenal untuk membantu siswa memahami dan mengingatkan materi yang mereka baca adalah strategi PQ4R (dalam Trianto, 2011:151).
Strategi PQ4R merupakan salah satu strategi pembelajaran yang digunakan untuk membantu siswa mengingat apa yang mereka baca dan membantu proses pembelajaran di kelas yang dilaksanakan dengan kegiatan membaca buku. Strategi pembelajaran ini didasari oleh teori bahwa mengajar yang baik mencakup mengajari siswa bagaimana belajar, mengingat, berpikir, dan mendorong diri sendiri (Suprijono, 2013:103). Dalam paparan yang lain juga dijelaskan bahwa proses pembelajaran membaca dengan strategi PQ4R akan meningkatkan kemampuan pemahaman yang tinggi yang dilandasi oleh konsentrasi yang baik pada saat membaca dan mampu digunakan untuk mengingat informasi dalam jangka waktu yang lama (Abidin, 2012:100).

Strategi PQ4R mempunyai tahapan dalam penerapannya, antara lain: (1) preview, artinya membaca selintas dengan cepat, (2) question, artinya mengajukan pertanyaanpertanyaan kepada diri sendiri untuk setiap pasal yang ada pada bahan bacaan siswa, (3) read, artinya membaca karangan itu secara aktif, (4) reflect, artinya siswa tidak hanya cukup untuk mengingat atau menghafal, tetapi cobalah untuk memahami informasi, (5) recite, artinya merenungkan kembali informasi yang telah dipelajari dengan menyatakan butir-butir penting dengan nyaring dan dengan menanyakan dan menjawab pertanyaan-pertanyaan, dan (6) 
review, artinya siswa membaca catatan singkat yang dibuatnya, mengulang kembali seluruh isi bacaan bila perlu dan sekali lagi menjawab pertanyaan-pertanyaan yang diajukan (Trianto, 2011:151153).

Penerapan strategi PQ4R dalam pembelajaran membaca dapat dilakukan dengan mengombinasikan tahapan membaca dengan tahapan strategi PQ4R yang digunakan. sebelumnya bahwa terdapat tiga tahapan dalam kegiatan membaca, yaitu prabaca, saat baca, dan pascabaca. Sedangkan tahapan strategi PQ4R ada enam tahapan, yaitu: preview, question, read, reflect, recite, and review. Pengombinasian ini diharapkan mampu meningkatkan keterampilan siswa dalam membaca pemahaman di kelas VI SD. Untuk lebih jelasnya dapat dilihat pada bagan 1 berikut.

Seperti apa yang telah dijelaskan

Keterampilan Membaca Pemahaman Siswa Kelas VI SDN 10 Lembah

Melintang Kab. Pasaman Barat Masih Rendah

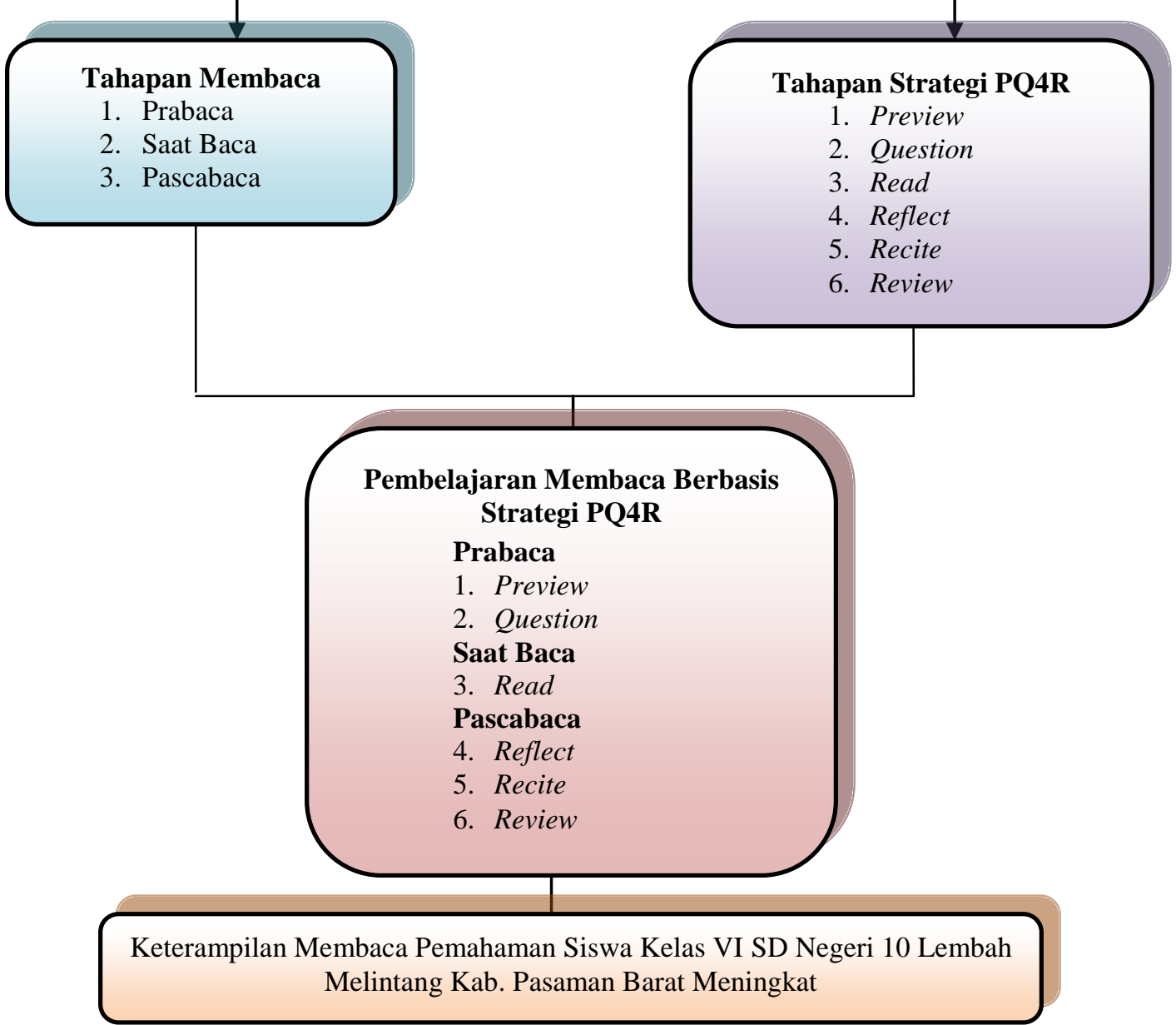

Bagan 1. Kerangka Berpikir Peningkatan Keterampilan Membaca Pemahaman dengan Menggunakan Strategi PQ4R di Kelas VI SD 
Berdasarkan paparan di atas, terdapat tiga masalah utama dalam penelitian ini, antara lain:

1. Bagaimanakah peningkatan keterampilan membaca pemahaman pada tahap prabaca dengan menggunakan strategi PQ4R di kelas VI SD Negeri 10 Lembah Melintang Kab. Pasaman Barat?

2. Bagaimanakah peningkatan keterampilan membaca pemahaman pada tahap saat baca dengan menggunakan strategi PQ4R di kelas VI SD Negeri 10 Lembah Melintang Kab. Pasaman Barat?

3. Bagaimanakah peningkatan keterampilan membaca pemahaman pada tahap pascabaca dengan menggunakan strategi PQ4R di kelas VI SD Negeri 10 Lembah Melintang Kab. Pasaman Barat?

\section{METODE PENELITIAN \\ Rancangan Penelitian}

Jenis penelitian adalah Penelitian Tindakan Kelas (PTK). Penelitian Tindakan Kelas (Classroom Action Research) merupakan penelitian yang dilakukan pada sebuah kelas untuk mengetahui akibat tindakan yang diterapkan pada suatu subjek penelitian di kelas tersebut (Paizaluddin, dkk., 2013:67). Lebih lanjut dijelaskan bahwa penelitian tindakan kelas dilakukan melalui proses yang dinamis dan komplementari yang terdiri dari empat "momentum" essensial, yaitu: perencanaan (planning), pelaksanaan (action), pengamatan (observation), dan refleksi (reflection) (Kunandar, 2010:70).

Pendekatan yang digunakan dalam penelitian ini adalah pendekatan kualitatif dan kuantitatif. Pendekatan ini berkenaan dengan perbaikan atau peningkatan proses pembelajaran di kelas yang diteliti, dalam hal ini berkaitan dengan peningkatan keterampilan membaca pemahaman di kelas VI SD. Pendekatan kualitatif merupakan prosedur penelitian yang menghasilkan data diskriptif berupa kata-kata tertulis atau lisan serta perilaku yang dapat diamati dari orang-orang atau sumber informasi, sedangkan kuantitatif merupakan prosedur penelitian yang menghasilkan data berupa angka.

\section{Sumber Data}

Sumber data penelitian berupa hasil observasi, pencatatan lapangan, dan dokumentasi dari setiap tindakan proses pembelajaran membaca dengan menggunakan strategi PQ4R di kelas VI SD Negeri 10 Lembah Melintang Kab. Pasaman Barat. Data tersebut tentang hal-hal yang berkaitan dengan pelaksanaan proses pembelajaran membaca pada tahap prabaca, saat baca, dan pascabaca sesuai dengan strategi PQ4R yang digunakan.

\section{Teknik Pengumpulan Data}

Teknik pengumpulan data dikumpulkan dengan menggunakan 
observasi, pencatatan lapangan, dan dokumentasi. Observasi bertujuan untuk mengamati berlangsungnya pembelajaran membaca pemahaman dengan menggunakan strategi PQ4R. Dengan berpedoman pada lembar observasi, observer mengamati apa yang terjadi selama proses pembelajaran ditandai dengan memberikan ceklis $(\sqrt{ })$ di kolom yang ada pada lembar observasi.

Catatan lapangan merupakan catatan yang dibuat peneliti dalam sebuah penelitian dari lapangan. Catatan tersebut dapat bersifat deskriptif (sesuai yang teramati) atau reflektif (tergantung penafsiran peneliti). Berbagai hasil pengamatan tentang aspek pembelajaran di kelas, suasanan kelas, pengelolaan kelas, interaksi praktisi (guru) dengan siswa, interaksi siswa dengan siswa, dan beberapa aspek lainnya dapat dicatat pada catatan lapangan dan akan digunakan sebagai salah satu sumber data penelitian tindakan kelas.

Dokumentasi adalah catatan peristiwa yang sudah berlalu, baik berbentuk tulisan maupun gambar. Dokumentasi itu digunakan untuk kegiatan-kegiatan penting dari proses pembelajaran membaca pemahaman dengan menggunakan strategi PQ4R sehingga dapat melengkapi data lapangan yang terjadi bila ada hal yang terlepas dari pengamatan peneliti, berupa foto-foto, rekaman video, atau data lainnya pada saat proses pembelajaran membaca pemahaman dengan menggunakan strategi PQ4R.

\section{Analisis Data}

Data yang diperoleh dalam penelitian dianalisis dengan menggunakan model analisis data kualitatif dan kuantitatif. Model analisis data kualitatif yaitu analisis data yang dimulai dengan menelaah data sejak pengumpulan data sampai seluruh data terkumpul. Data tersebut direduksi berdasarkan masalah yang diteliti, diikuti penyajian data, dan terakhir penyimpulan atau verifikasi.

Model analisis kuantitatif yaitu terhadap hasil belajar siswa dengan menggunakan persentase yang dikemukakan Purwanto (2010:102) sebagai berikut.

$\mathrm{NP}=\frac{\mathrm{R}}{\mathrm{SM}} \times 100 \%$

Keterangan:

$\mathrm{NP}=$ Nilai persen yang dicari atau diharapkan

$\mathrm{R} \quad=$ Skor mentah yang diperoleh oleh siswa

$\mathrm{SM}=$ Skor maksimum dari tes tersebut

Berdasarkan analisis data di atas, kriteria keberhasilan dapat dilihat pada keterangan berikut (Taufik dan Muhammadi, 2011:224).

$80 \%-100 \%$ : A (Sangat Baik)

$70 \%-79 \%$ : B (Baik)

$60 \%-69 \%:$ C (Cukup)

$59 \% \quad:$ K (Kurang)

Merujuk pada Permendikbud Nomor 104 Tahun 2014 tentang ketuntasan belajar untuk aspek keterampilan ditetapkan dengan capaian minimum B (Baik), artinya keberhasilan membaca pemahaman 
siswa hendaknya berada pada rentang nilai $70 \%-79 \%$.

Proses jalannya penelitian yang dilakukan diberikan dengan gambaran alur penelitian. Alur penelitian secara sederhana dapat dilihat pada bagan 2 berikut.

Studi Pendahuluan: Observasi proses pembelajaran membaca pemahaman di kelas VI SD untuk mengidentifikasi masalah
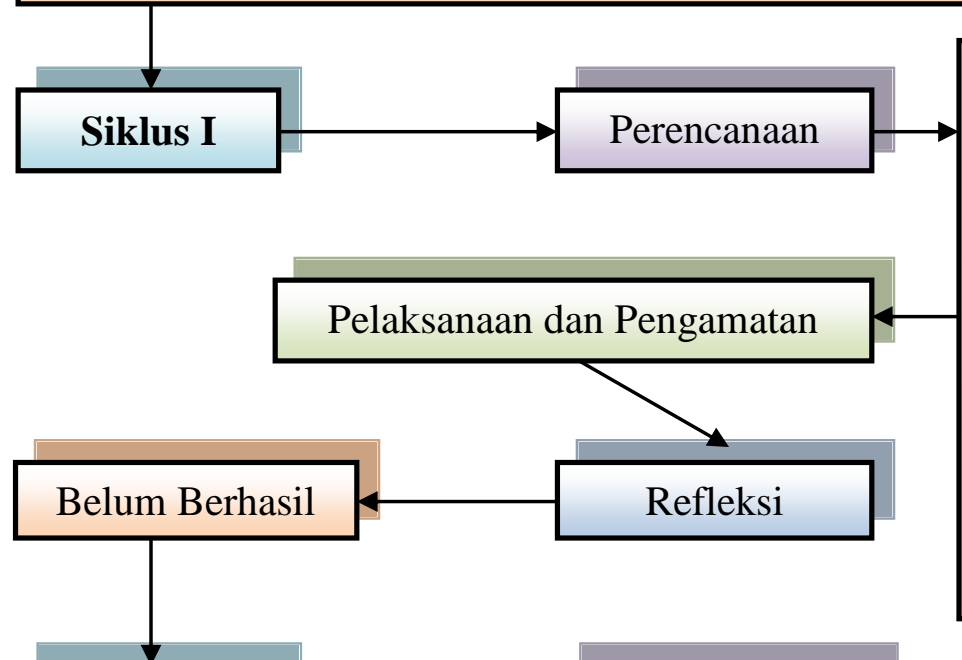

Siklus II

\section{Perencanaan}

Laporan Berhasil Refleksi

\section{Pembelajaran Membaca}

Berbasis Strategi PQ4R

Prabaca

1. Preview

2. Question

Saat Baca

3. Read

Pascabaca

4. Reflect

5. Recite

6. Review

Pembelajaran Membaca Berbasis Strategi PQ4R Prabaca

1. Preview

2. Question

Saat Baca

3. Read

Pascabaca

4. Reflect

5. Recite

6. Review

\section{Bagan 2. Alur Penelitian Tindakan Kelas}

\section{HASIL PENELITIAN DAN PEMBAHASAN}

Hasil penelitian tentang peningkatan keterampilan membaca pemahaman dengan strategi PQ4R di kelas VI SD Negeri 10 Lembah Melintang Kab. Pasaman Barat dijabarkan dalam dua siklus dengan tiga tahapan utama, yaitu: tahap prabaca, saat baca, dan pascabaca.

Untuk lebih jelasnya, dapat dilihat pada jabaran berikut. 
Siklus I

Hasil penelitian siklus I meliputi: (1) peningkatan keterampilan membaca pemahaman dengan strategi PQ4R di kelas VI SD Negeri 10 Lembah Melintang Kab. Pasaman Barat pada tahap prabaca, (2) peningkatan keterampilan membaca pemahaman dengan strategi PQ4R di kelas VI SD Negeri 10 Lembah Melintang Kab. Pasaman Barat pada tahap saat baca, dan (3) peningkatan keterampilan membaca pemahaman dengan strategi PQ4R di kelas VI SD Negeri 10 Lembah
Melintang Kab. Pasaman Barat pada tahap pascabaca. Untuk lebih jelasnya dapat dilihat pada uraian berikut.

\section{Tahap Prabaca}

Kegiatan yang dilakukan pada tahap prabaca adalah memprediksi isi bacaan. Caranya dengan mengajukan 5 item pertanyaan terkait dengan isi teks yang akan dibaca. Setelah siswa menjawab pertanyaan yang diberikan, dilakukan penilaian dengan instrumen sebagai berikut.

Tabel 1. Instrumen Penilaian Tahap Prabaca Siklus I

\begin{tabular}{|c|l|}
\hline Kriteria & \multicolumn{1}{|c|}{ Deskriptor } \\
\hline $\begin{array}{c}\text { (Sangat Baik) } \\
3\end{array}$ & $\begin{array}{l}\text { Jika siswa mampu mengisi jawaban dari seluruh soal } \\
\text { prediksi dan jawaban benar. }\end{array}$ \\
\hline $\begin{array}{c}\text { (Baik) } \\
2\end{array}$ & $\begin{array}{l}\text { Jika siswa hanya mampu mengisi 4 dari keseluruhan } \\
\text { soal prediksi dan jawaban benar. }\end{array}$ \\
\hline Cukup) & $\begin{array}{l}\text { Jika siswa hanya mampu mengisi 3 dari keseluruhan } \\
\text { soal prediksi dan jawaban benar. }\end{array}$ \\
\hline 1 & $\begin{array}{l}\text { Jika siswa mampu mengisi 1-2 dari keseluruhan soal } \\
\text { prediksi dan jawaban benar. }\end{array}$ \\
\hline
\end{tabular}

Sumber: Diadopsi dari Abidin (2012:278)

Berdasarkan instrumen penilaian di atas, diperoleh beberapa hal di antaranya: siswa masih kesulitan dalam membuat prediksi isi bacaan dan banyak siswa yang menulis prediksi yang jauh dengan isi cerita yang sebenarnya. Jika ditelaah lebih lanjut, penyebab terjadi sulitnya siswa dalam membuat prediksi isi bacaan adalah guru belum membimbing siswa merumuskan jawaban pertanyaan sesuai dengan isi bacaan yang sesunggguhnya. Perlu dipahami bahwa tingkat kecerdasan siswa tidaklah sama. Daya tangkap dan daya serap serta tafsiran siswa berbeda-beda. Ada yang memiliki daya tangkap yang cepat dalam memahami sesuatu, ada juga yang lambat. Siswa yang lambat memahami sesuatu, berarti ia dikatakan kurang cerdas. Siswa yang kurang cerdas membutuhkan pendekatan khusus, caranya dengan mengarahkan mereka sesuai dengan apa yang dituju dengan baik (Rahman, 2013:174).

Selanjutnya, penyebab terjadi banyaknya jawaban siswa yang 
masih jauh dari isi bacaan yang sebenarnya adalah rumusan pertanyaan yang diajukan guru kurang dapat dipahami dari aspek keterbacaan maupun konten (isi) pertanyaan. Maksudnya, redaksi bahasa pertanyaan yang diajukan kurang jelas dan isi pertanyaan yang diajukan merupakan pertanyaan yang jarang di dengar oleh siswa dan jarang dialami oleh siswa. Oleh sebab itu, adalah suatu hal yang wajar jika masih banyak siswa yang menulis isi prediksi masih jauh dari isi bacaan yang sebenarnya.

Berdasarkan hasil analisis penelitian, keterampilan membaca pemahaman siswa pada siklus I tahap prabaca, diperoleh persentase keberhasilan $65 \%$ dengan kriteria Cukup (C). Hal ini menunjukkan bahwa siswa belum mampu mengisi keseluruhan dari total item pertanyaan prediksi isi bacaan. Jika merujuk pada apa yang disampaikan oleh Permendikbud Nomor 104 Tahun 2014 tentang ketuntasan belajar untuk aspek keterampilan ditetapkan dengan capaian minimum B (Baik), artinya keberhasilan membaca pemahaman siswa hendaknya berada pada rentang nilai 70\%-79\%. Berdasarkan hasil tersebut dapat disimpulkan bahwa pelaksanaan pembelajaran membaca pada tahap prabaca pada siklus I perlu ditingkatkan agar keterampilan membaca pemahaman meningkat pada siklus II. Kekurangankekurangan pada siklus I diharapkan tidak ditemukan lagi pada siklus II. Oleh karena itu perlu dilakukan persiapan yang lebih baik.

\section{Tahap Saat Baca}

Kegiatan yang dilakukan pada tahap saat baca adalah menguji kebenaran prediksi isi bacaan berdasarkan teks yang dibaca. Instrumen yang digunakan dalam menilai uji prediksi hampir sama dengan penilaian ketika tahap prabaca. Untuk lebih jelasnya, dapat dilihat pada tabel 2 berikut.

\section{Tabel 2. Instrumen Penilaian Tahap Saat Baca Siklus I}

\begin{tabular}{|c|l|}
\hline Kriteria & \multicolumn{1}{|c|}{ Deskriptor } \\
\hline $\begin{array}{c}\text { (Sangat Baik) } \\
3\end{array}$ & $\begin{array}{l}\text { Jika siswa mampu mengisi jawaban dari seluruh soal } \\
\text { uji prediksi dan jawaban benar. }\end{array}$ \\
\hline $\begin{array}{c}\text { (Baik) } \\
2\end{array}$ & $\begin{array}{l}\text { Jika siswa hanya mampu mengisi 4 dari keseluruhan } \\
\text { soal uji prediksi dan jawaban benar. }\end{array}$ \\
\hline Cukup) & $\begin{array}{l}\text { Jika siswa hanya mampu mengisi 3 dari keseluruhan } \\
\text { soal uji prediksi dan jawaban benar. }\end{array}$ \\
\hline 1 & $\begin{array}{l}\text { Jika siswa mampu mengisi 1-2 dari keseluruhan soal } \\
\text { uji prediksi dan jawaban benar. }\end{array}$ \\
\hline
\end{tabular}

Sumber: Diadopsi dari Abidin (2012:278)

Berdasarkan instrumen penilaian di atas, diperoleh gambaran bahwa masih terdapat kesulitan siswa menjawab soal uji prediksi walaupun telah membaca teks bacaan secara utuh. Jika ditelaah lebih lanjut, 
penyebab terjadinya kesulitan itu adalah guru belum menjelaskan teknik membaca yang benar agar siswa memahami bacaan dengan baik. Akibatnya siswa masih banyak yang melakukan kebiasaan lama dalam membaca, misalnya mulut komat-kamit atau menunjuk teks bacaan ketika membaca. Telah dijelaskan sebelumnya bahwa terdapat teknik membaca pemahaman yang benar, yaitu membaca dengan tidak bersuara, bibir tidak bergerak atau komatkamit, tidak menggerakkan kepala mengikuti baris bacaan, tidak menunjuk baris bacaan dengan jari, pensil, atau alat lainnya, dan tidak membaca kata demi kata, atau kalimat demi kalimat (Saddhono dan St.Y.Slamet, 2012:66). Oleh karena itu guru hendaknya menjelaskan teknik membaca yang sesuai agar siswa dapat memahami isi bacaan dengan baik.

Berdasarkan paparan di atas, hasil uji prediksi pada siklus I memperoleh persentase $69 \%$ dengan kriteria Cukup (C) karena secara umum siswa hanya mampu mengisi 2 dari keseluruhan soal uji prediksi. Jika merujuk pada apa yang disampaikan oleh Permendikbud Nomor 104 Tahun 2014 tentang ketuntasan belajar untuk aspek keterampilan ditetapkan dengan capaian minimum B (Baik), artinya keberhasilan membaca pemahaman siswa hendaknya berada pada rentang nilai 70\%-79\%. Dengan demikian, dapat disimpulkan bahwa pada pembelajaran membaca pemahaman tahap saat baca siklus I belum berjalan dengan baik dan belum berhasil sesuai harapan.

\section{Tahap Pascabaca}

Kegiatan yang dilakukan pada tahap pascabaca adalah menganggapi informasi dari teks yang dibaca dan meringkas isi bacaan. Instrumen yang digunakan dalam menilai keterampilan membaca pemahaman pada tahap pascabaca sebagai berikut.

\section{Tabel 3. Instrumen Penilaian Menanggapi Informasi dari Teks yang Dibaca Siklus I}

\begin{tabular}{|c|l|}
\hline Kriteria & \multicolumn{1}{c|}{ Deskriptor } \\
\hline $\begin{array}{c}4 \\
\text { (Sangat Baik) }\end{array}$ & Memberikan tanggapan dengan lengkap dan jelas \\
\hline $\begin{array}{c}3 \\
\text { (Baik) }\end{array}$ & $\begin{array}{l}\text { Memberikan tanggapan dengan kurang lengkap, } \\
\text { namun jelas }\end{array}$ \\
\hline $\begin{array}{c}2 \\
\text { (Cukup) }\end{array}$ & $\begin{array}{l}\text { Memberikan tanggapan dengan tidak lengkap dan } \\
\text { kurang jelas }\end{array}$ \\
\hline $\begin{array}{c}1 \\
(\text { Kurang) }\end{array}$ & Tidak mampu memberikan tanggapan \\
\hline
\end{tabular}

Sumber: Diadopsi dari Abidin (2012:278) 
Tabel 4. Instrumen Penilaian Meringkas Isi Bacaan Siklus I

\begin{tabular}{|c|l|}
\hline Kriteria & \multicolumn{1}{|c|}{ Deskriptor } \\
\hline $\begin{array}{c}\text { (Sangat Baik) } \\
3\end{array}$ & $\begin{array}{l}\text { Meringkas seluruh isi teks dengan bahasa sendiri dan } \\
\text { urutan benar }\end{array}$ \\
\hline $\begin{array}{c}\text { Meringkas seluruh isi teks dengan bahasa sendiri } \\
\text { namun dengan urutan yang kurang benar }\end{array}$ \\
\hline 2 \\
(Cukup) & $\begin{array}{l}\text { Meringkas sebagian besar isi teks dengan bahasa } \\
\text { sendiri dan urutan kurang benar }\end{array}$ \\
\hline 1 & $\begin{array}{l}\text { Meringkas sebagian kecil isi teks dengan bahasa } \\
\text { sendiri dan urutan kurang benar }\end{array}$ \\
\hline
\end{tabular}

Sumber: Diadopsi dari Abidin (2012:278)

Berdasarkan hasil pengamatan dengan menggunakan instrumen penilaian di atas, siswa masih banyak yang belum mampu memberikan tanggapan dan meringkas isi teks secara keseluruhan dengan tepat. Jika ditelaah lebih lanjut, penyebab terjadinya hal tersebut adalah kurangnya motivasi dari guru terhadap siswa ketika mencoba memberikan tanggapan, misalnya saja "ananda pasti bisa", dan sebagainya. Penyebab lainnya adalah rendahnya pemahaman siswa dalam membaca ketika tahap saat baca sebelumnya sehingga berdampak pada sulitnya siswa dalam membuat ringkasan isi bacaan. Nilai yang diperoleh pada tahap pascabaca adalah 66\% dengan kriteria Cukup (C). Jika merujuk pada apa yang disampaikan oleh Permendikbud Nomor 104 Tahun 2014 tentang ketuntasan belajar untuk aspek keterampilan ditetapkan dengan capaian minimum B (Baik), artinya keberhasilan membaca pemahaman siswa hendaknya berada pada rentang nilai 70\%-79\%. Dengan demikian, dapat disimpulkan bahwa pada pembelajaran membaca pemahaman tahap pascabaca siklus I belum juga berjalan dengan baik dan belum berhasil sesuai harapan. Kekurangan atau kelemahan yang terjadi pada siklus I hendaknya dapat diminimalisir pada siklus II agar dapat memberikan dampak yang positif sebagai upaya meningkatkan pemahaman siswa dalam membaca.

\section{Siklus II}

Hasil penelitian siklus II hampir sama dengan siklus I sebelumnya, namun perbedaannya hanya pada judul teks yang dibaca. Terdapat tiga hal utama yang akan diamati pada siklus II, yaitu: (1) peningkatan keterampilan membaca pemahaman dengan strategi PQ4R di kelas VI SD Negeri 10 Lembah Melintang Kab. Pasaman Barat pada tahap prabaca, (2) peningkatan keterampilan membaca pemahaman dengan strategi PQ4R di kelas VI SD Negeri 10 Lembah Melintang Kab. Pasaman Barat pada tahap saat baca, dan (3) peningkatan keterampilan membaca pemahaman dengan strategi PQ4R di kelas VI SD Negeri 10 Lembah Melintang Kab. Pasaman Barat pada tahap pascabaca. Untuk 
lebih jelasnya dapat dilihat pada uraian berikut.

\section{Tahap Prabaca}

Kegiatan yang dilakukan pada tahap prabaca siklus II sama dengan siklus I sebelumnya yaitu memprediksi isi bacaan. Caranya dengan mengajukan 5 item pertanyaan terkait dengan isi teks yang akan dibaca. Setelah siswa menjawab pertanyaan yang diberikan, dilakukan penilaian dengan instrumen sebagai berikut.

\section{Tabel 5. Instrumen Penilaian Tahap Prabaca Siklus II}

\begin{tabular}{|c|l|}
\hline Kriteria & \multicolumn{1}{|c|}{ Deskriptor } \\
\hline $\begin{array}{c}\text { (Sangat Baik) } \\
3\end{array}$ & $\begin{array}{l}\text { Jika siswa mampu mengisi jawaban dari seluruh soal } \\
\text { prediksi dan jawaban benar. }\end{array}$ \\
\hline $\begin{array}{c}\text { Jika siswa hanya mampu mengisi 4 dari keseluruhan } \\
\text { soal prediksi dan jawaban benar. }\end{array}$ \\
\hline 2 & $\begin{array}{l}\text { Jika siswa hanya mampu mengisi 3 dari keseluruhan } \\
\text { soal prediksi dan jawaban benar. }\end{array}$ \\
\hline $\begin{array}{c}\text { (Cukup) } \\
\text { (Kurang) }\end{array}$ & $\begin{array}{l}\text { Jika siswa mampu mengisi 1-2 dari keseluruhan soal } \\
\text { prediksi dan jawaban benar. }\end{array}$ \\
\hline
\end{tabular}

Sumber: Diadopsi dari Abidin (2012:278)

Berdasarkan instrumen penilaian yang digunakan di atas, secara umum siswa sudah mampu mengisi jawaban soal prediksi walaupun terkadang masih kurang tepat. Hasil analisis penelitian, keterampilan membaca pemahaman siswa pada siklus II tahap prabaca, diperoleh persentase keberhasilan 75\% dengan kriteria Baik (B). Hal ini menunjukkan bahwa siswa sudah mampu memprediksi sebagain besar dari total keseluruhan pertanyaan prediksi isi bacaan. Jika merujuk pada apa yang disampaikan oleh Permendikbud Nomor 104 Tahun 2014 tentang ketuntasan belajar untuk aspek keterampilan ditetapkan dengan capaian minimum B (Baik), artinya keberhasilan membaca pemahaman siswa hendaknya berada pada rentang nilai $70 \%-79 \%$. Berdasarkan hasil tersebut dapat disimpulkan bahwa pelaksanaan pembelajaran membaca pada tahap prabaca pada siklus II sudah berjalan dengan baik dan sesuai dengan harapan.

\section{Tahap Saat Baca}

Kegiatan yang dilakukan pada tahap saat baca siklus II juga sama dengan siklus I sebelumnya yaitu menguji kebenaran prediksi isi bacaan berdasarkan teks yang dibaca. Instrumen yang digunakan dalam menilai uji prediksi pada tahap saat baca sebagai berikut. 
Tabel 6. Instrumen Penilaian Tahap Saat Baca Siklus II

\begin{tabular}{|c|l|}
\hline Kriteria & \multicolumn{1}{c|}{ Deskriptor } \\
\hline $\begin{array}{c}\text { (Sangat Baik) } \\
3\end{array}$ & $\begin{array}{l}\text { Jika siswa mampu mengisi jawaban dari seluruh soal } \\
\text { uji prediksi dan jawaban benar. }\end{array}$ \\
\hline $\begin{array}{c}\text { (Baik) } \\
2\end{array}$ & $\begin{array}{l}\text { Jika siswa hanya mampu mengisi 4 dari keseluruhan } \\
\text { soal uji prediksi dan jawaban benar. }\end{array}$ \\
\hline Cukup) & $\begin{array}{l}\text { Jika siswa hanya mampu mengisi 3 dari keseluruhan } \\
\text { soal uji prediksi dan jawaban benar. }\end{array}$ \\
\hline 1 & $\begin{array}{l}\text { Jika siswa mampu mengisi 1-2 dari keseluruhan soal } \\
\text { uji prediksi dan jawaban benar. }\end{array}$ \\
\hline
\end{tabular}

Sumber: Diadopsi dari Abidin (2012:278)

Berdasarkan instrumen penilaian di atas, diperoleh gambaran bahwa sebagaian besar siswa sudah mampu menjawab soal uji prediksi secara lengkap dan tepat. Hasil uji prediksi pada siklus II memperoleh persentase $81 \%$ dengan kriteria Sangat Baik (SB). Jika merujuk pada apa yang disampaikan oleh Permendikbud Nomor 104 Tahun 2014 tentang ketuntasan belajar untuk aspek keterampilan ditetapkan dengan capaian minimum B (Baik), artinya keberhasilan membaca pemahaman siswa hendaknya berada pada rentang nilai 70\%-79\%. Dengan demikian, dapat disimpulkan bahwa pada pembelajaran membaca pemahaman tahap saat baca siklus II sudah berjalan dengan baik dan berhasil sesuai harapan.

\section{Tahap Pascabaca}

Kegiatan yang dilakukan pada tahap pascabaca siklus II juga sama dengan tahap pascabaca siklus I, yaitu menganggapi informasi dari teks yang dibaca dan meringkas isi bacaan. Instrumen yang digunakan dalam menilai keterampilan membaca pemahaman pada tahap pascabaca siklus II sebagai berikut.

\section{Tabel 7. Instrumen Penilaian Menanggapi Informasi dari Teks yang Dibaca Siklus II}

\begin{tabular}{|c|l|}
\hline Kriteria & \multicolumn{1}{c|}{ Deskriptor } \\
\hline $\begin{array}{c}4 \\
\text { (Sangat Baik) }\end{array}$ & Memberikan tanggapan dengan lengkap dan jelas \\
\hline $\begin{array}{c}3 \\
\text { Baik) }\end{array}$ & $\begin{array}{l}\text { Memberikan tanggapan dengan kurang lengkap, } \\
\text { namun jelas }\end{array}$ \\
\hline $\begin{array}{c}\text { (Cukup) } \\
1\end{array}$ & $\begin{array}{l}\text { Memberikan tanggapan dengan tidak lengkap dan } \\
\text { kurang jelas }\end{array}$ \\
\hline Kurang) & Tidak mampu memberikan tanggapan \\
\hline
\end{tabular}

Sumber: Diadopsi dari Abidin (2012:278) 
Tabel 8. Instrumen Penilaian Meringkas Isi Bacaan Siklus II

\begin{tabular}{|c|l|}
\hline Kriteria & \multicolumn{1}{|c|}{ Deskriptor } \\
\hline $\begin{array}{c}\text { (Sangat Baik) } \\
3\end{array}$ & $\begin{array}{l}\text { Meringkas seluruh isi teks dengan bahasa sendiri dan } \\
\text { urutan benar }\end{array}$ \\
\hline $\begin{array}{c}\text { Meringkas seluruh isi teks dengan bahasa sendiri } \\
\text { namun dengan urutan yang kurang benar }\end{array}$ \\
\hline 2 \\
(Cukup) & $\begin{array}{l}\text { Meringkas sebagian besar isi teks dengan bahasa } \\
\text { sendiri dan urutan kurang benar }\end{array}$ \\
\hline 1 & $\begin{array}{l}\text { Meringkas sebagian kecil isi teks dengan bahasa } \\
\text { sendiri dan urutan kurang benar }\end{array}$ \\
\hline
\end{tabular}

Sumber: Diadopsi dari Abidin (2012:278)

Berdasarkan hasil pengamatan dengan menggunakan instrumen penilaian di atas, siswa sudah mampu memberikan tanggapan dan meringkas isi teks secara keseluruhan dengan tepat. Nilai yang diperoleh pada tahap pascabaca adalah $78 \%$ dengan kriteria Baik (B). Jika merujuk pada apa yang disampaikan oleh Permendikbud Nomor 104 Tahun 2014 tentang ketuntasan belajar untuk aspek keterampilan ditetapkan dengan capaian minimum B (Baik), artinya keberhasilan membaca pemahaman siswa hendaknya berada pada rentang nilai 70\%-79\%. Dengan demikian, dapat disimpulkan bahwa pada pembelajaran membaca pemahaman tahap pascabaca siklus II sudah berjalan dengan baik dan berhasil sesuai harapan.

\section{KESIMPULAN}

Berdasarkan

uraian sebelumnya dapat disimpulkan bahwa penggunaan strategi PQ4R sebagai upaya meningkatkan pemahaman siswa dalam membaca pemahaman di kelas VI SD Negeri 10 Lembah Melintang Kabupaten Pasaman Barat telah berhasil dilaksanakan dengan baik. Hal ini terlihat dari kegiatan tahap prabaca, saat baca, dan pascabaca yang secara umum memberikan hasil yang sangat baik. Artinya, dengan strategi PQ4R siswa dapat memahami isi teks bacaan dengan baik, mampu menanggapi berbagai persoalan yang diajukan pada teks dengan baik, dan mampu merumuskan ringkasan isi teks secara umum sesuai isi teks yang sebenarnya. Oleh sebab itu, penggunaan strategi PQ4R layak dipertimbangkan sebagai upaya membangun sinergi pembelajaran membaca pemahaman di kelas VI SD. Perlu disadari bahwa membaca pemahaman tidaklah hanya dilakukan di kelas VI SD saja, melainkan sudah dimulai di kelas III s/d kelas VI SD. Oleh sebab itu, untuk menguji efektivitas penggunaan strategi PQ4R lebih lanjut, hendaknya dilakukan penelitian serupa di kelas-kelas lain 
terutama yang berkaitan dengan membaca pemahaman di SD. Dengan demikian, keterampilan membaca pemahaman siswa di SD hendaknya terus meningkat dari waktu ke waktu sesuai dengan harapan tujuan pendidikan nasional.

\section{DAFTAR RUJUKAN}

Abidin, Yunus. 2012. Pembelajaran Membaca Berbasis Pendidikan Karakter. Bandung: PT. Refika Aditama.

Ghazali,

A.Syukur. 2010. Pembelajaran Keterampilan Berbahasa dengan Pendekatan KomunikatifInteraktif. Bandung: Refika Aditama.

Kunandar. 2010. Guru Profesional Implementasi KTSP dan Sukses dalam Sertifikasi Guru. Jakarta: PT. Raja Grafindo Persada.

Paizaluddin, dkk. 2013. Penelitian Tindakan Kelas. Bandung: Alpabeta.

Peraturan Menteri Pendidikan Nasional Republik Indonesia Nomor 104 Tahun 2014 Tentang Penilaian Hasil Belajar oleh Pendidik pada Pendidikan Dasar dan Pendidikan Menengah.

Peraturan Pemerintah Republik

Indonesia Nomor 19 Tahun 2005 tentang Standar Nasional Pendidikan. 2006. Jakarta: Diperbanyak oleh Sinar Grafika.

Purwanto, Ngalim. 2010. PrinsipPrinsip dan Teknik Evaluasi
Pengajaran. Bandung: PT Remaja Rosdakarya.

Rahim, Farida. 2011. Pengajaran Membaca di Sekolah Dasar. Jakarta: Bumi Aksara.

Rahman, Masykur Arif. 2013. Kesalahan-Kesalahan Guru Saat Mengajar. Yogyakarta: Laksana.

Rubin, Dorothy. 1995. Teaching Elementary Language Art an Integrated Approach. USA: Allyn and Bacon.

Saddhono, Kundharu dan St.Y.Slamet. 2012. Meningkatkan Keterampilan Berbahasa Indonesia (Teori dan Aplikasi). Bandung: Karya Putra Darwati.

Somadayo, Samsu. 2011. Strategi dan Teknik Pembelajaran Membaca. Yogyakarta: Graha Ilmu.

Stone, Randi. 2013. Best Practices for Teaching Reading. California: Corwin Press.

Suprijono, Agus. 2013. Cooperative Learning, Teori dan aplikasi PAIKEM. Yogyakarta: Pustaka Pelajar.

Taufik, Taufina, dan Muhammadi. 2011. Mozaik Pembelajaran Inovatif. Padang: Sukabina Press.

Trianto. 2011. Mendesain Model Pembelajaran InovatifProgresif. Jakarta: Kencana. 